CLINICAL STUDY

\title{
Differential gene expression in ACTH -secreting and non-functioning pituitary tumors
}

Toru Tateno, Hajime Izumiyama, Masaru Doi, Takanobu Yoshimoto, Masayoshi Shichiri, Naoko Inoshita ${ }^{1}$, Kenichi Oyama ${ }^{2}$, Shozo Yamada ${ }^{2}$ and Yukio Hirata

Department of Clinical and Molecular Endocrinology, Tokyo Medical and Dental University Graduate School, 1-5-45, Yushima, Bunkyo-ku, Tokyo, Japan, Departments of ${ }^{1}$ Pathology and ${ }^{2}$ Hypothalamic and Pituitary Surgery, Toranomon Hospital, Tokyo, Japan

(Correspondence should be addressed to T Tateno; Email: ttateno.cme@tmd.ac.jp)

\begin{abstract}
Objective: Differential expression of several genes between ACTH-secreting pituitary tumors causing Cushing' disease (CD), silent corticotroph adenoma (SCA), and non-functioning pituitary tumors (NFT) was investigated.

Design and methods: We used tissue specimens from 35 pituitary tumors (12 CD, 8 SCA, and 15 NFT). Steady-state mRNA levels of the genes related to proopiomelanocortin (POMC) transcription, synthesis, processing, and secretion, such as neurogenic differentiation 1 (NeuroD1), T-box 19 (Tpit), corticotropin releasing hormone receptor (CRHR), vasopressin receptor $1 \mathrm{~b}$ (V1bR), prohormone

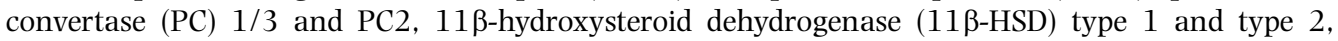
glucocorticoid receptor $\alpha(\mathrm{GR} \alpha)$, annexin A1, histone deacetylase 2 (HDAC2), and BRM/SWI2-related gene 1 , were determined by real-time RT-PCR.

Results and conclusion: POMC and Tpit mRNA levels were greater in CD and SCA than those in NFT. NeuroD1 mRNA levels were less in CD than those in NFT, but almost comparable between SCA and NFT. PC1/3 mRNA levels were greater in CD, but less in SCA than those in NFT. PC2 mRNA levels in CD and SCA were less than those in NFT. CRHR, V1bR, and 11 $\beta$-HSD2 mRNA levels in CD were greater than those in SCA and NFT. HDAC2 mRNA levels in CD and SCA were lower than those in NFT. In conclusion, our study demonstrated that the genes related to transcription, synthesis, processing, and secretion of POMC are differentially regulated in ACTH-secreting pituitary tumors causing CD and SCA compared with those in NFT. This may partly explain the development of clinically active and inactive CD.
\end{abstract}

European Journal of Endocrinology 157 717-724

\section{Introduction}

In adrenocorticotrophin (ACTH)-secreting pituitary tumors causing Cushing's disease (CD), hypercortisolemia induces a diversity of clinical manifestations, including moon face, central obesity, diabetes, hypertension, osteoporosis, and so on. By contrast, silent corticotroph adenoma (SCA) is defined as a pituitary adenoma with positive immunoreactivity for ACTH without any signs and symptoms of Cushing's syndrome (1). In SCA, plasma ACTH levels are usually normal (2). Neither the mechanism(s) for the dysregulation of ACTH secretion in ACTH-secreting pituitary tumors nor the mechanism(s) accounting for the lack of Cushingoid features in SCA are fully understood.

Possible differential expression of a variety of genes related to proopiomelanocortin (POMC) transcription, synthesis, processing, transport, and secretion between ACTH-secreting pituitary tumors and non-functioning pituitary tumors (NFT) could be postulated. Two previous studies using DNA microarrays revealed that a limited number of genes related to tumorigenesis are differentially expressed in pituitary tumors $(3,4)$. However, to the best of our knowledge, the expression profile of the genes related to POMC transcription, synthesis, processing, secretion, and intracellular trafficking in ACTH-secreting pituitary tumors and NFT have not been extensively studied to date. Therefore, the present study was designed to investigate the expression profile of a variety of such genes in tumor tissues obtained from surgery using a quantitative reverse transcriptase-PCR (RT-PCR) technique.

\section{Patients and methods}

\section{Patients}

Thirty-five patients (13 male and 22 female, mean age $47.8 \pm 2.6$ years old), who underwent transsphenoidal surgery for removal of pituitary tumors at the Department of Hypothalamic and Pituitary Surgery, Toranomon Hospital, were studied. Informed consent was obtained from each patient before surgery. Based on clinical, 
endocrinological, and immunohistochemical study, 12 were diagnosed as CD, 8 as SCA, and 15 as NFT. The diagnosis of CD was made based on signs and symptoms of Cushing's syndrome, endocrine data (increased plasma ACTH and serum cortisol concentrations, lack of diurnal rhythm, suppression after high-dose ( $8 \mathrm{mg}$ ) dexamethasone, and/or hyperresponse of ACTH to corticotropin releasing hormone, $\mathrm{CRH}$ ), and the presence of a pituitary tumor by diagnostic magnetic resonance image, which was confirmed by the demonstration of positive immunoreactivity for ACTH in pituitary tumor cells. The diagnosis of SCA was based on positive immunoreactivity for ACTH in pituitary tumor cells without any signs or symptoms of Cushing's syndrome.

The female-to-male ratio of ACTH-secreting tumors (CD and SCA) was greater $(P<0.01)$ than that in NFT. Patients with CD (38.6 \pm 4.6 years old) were significantly $(P<0.05)$ younger than those with SCA $(52.1 \pm 3.4$ years old) and NFT ( $52.9 \pm 4.6$ years old). The tumor sizes in CD $(11.8 \pm 2.2 \mathrm{~mm})$ were significantly $(P<0.05)$ smaller than those in SCA $(42.8 \pm 12.2 \mathrm{~mm})$ and NFT $(30.2 \pm$ $2.0 \mathrm{~mm})$. Both plasma ACTH levels $(172.2 \pm 30.6 \mathrm{pg} / \mathrm{ml})$ and serum cortisol levels $(33.5 \pm 4.8 \mu \mathrm{g} / \mathrm{dl})$ in CD were significantly $(P<0.01)$ higher than those in SCA (ACTH $29.9 \pm 4.5 \mathrm{pg} / \mathrm{ml}$, cortisol $9.9 \pm 1.6 \mu \mathrm{g} / \mathrm{dl})$ and NFT (ACTH $29.9 \pm 5.3 \mathrm{pg} / \mathrm{ml}$, cortisol $13.4 \pm 1.4 \mu \mathrm{g} / \mathrm{dl}$ ) respectively.

\section{Preparation of tissue specimens}

Tissue specimens were obtained during transsphenoidal surgery from each pituitary tumor. A portion of the surgical tissue specimens was immediately frozen with RNAlater (Ambion Inc., Austin, TX, USA) in liquid nitrogen and stored at $-80{ }^{\circ} \mathrm{C}$. The remaining tissue specimens were subjected to histological and immunohistochemical studies.

\section{Quantification of mRNA}

Total RNA was extracted from pituitary tumors (30-200 mg) using the TRIzol reagent protocol (Life Technologies Inc). Five micrograms total RNA were reverse transcribed with a first-strand synthesis kit (GE Healthcare, Chalfont, Buckinghamshire, UK). mRNA levels of POMC, neurogenic differentiation 1 (NeuroD1), T-box 19 (Tpit), CRH receptor (CRHR), vasopressin receptor $1 \mathrm{~b}(\mathrm{~V} 1 \mathrm{bR})$, prohormone convertase $(\mathrm{PC}) 1 / 3$, PC2, $11 \beta$-hydroxysteroid dehydrogenase 1 and -2 (11 $\beta$ HSD1, -2), glucocorticoid receptor $\alpha(\mathrm{GR} \alpha)$, annexin A1 (ANXA1), histone deacetylase 2 (HDAC2), BRM/SWI2related gene 1 (Brg1), Ras-associated protein 3 (Rab3), syntaxin6, and membrane associated ring finger protein 2 (MARCH2), were quantified with real-time RT-PCR using fluorescent SYBR green technology (LightCycler: Roche Molecular Biochemicals). The PCR primers of the genes were synthesized by Greiner bio-one (Tokyo, Japan) and their sequences are shown in Table 1. In the SYBR green real-time PCR method, fluorescence data were quantitatively analyzed using serial dilution of control samples included in each reaction to produce a standard curve. To compare the relative expression of each gene, glyceraldehyde-3-phosphate dehydrogenase (GAPDH) was used as an endogenous internal control and the relative levels of each mRNA to that of GAPDH were calculated.

\section{Statistical analysis}

Data were expressed as means \pm s.E.M. Differences between groups were examined for statistical significance using unpaired $t$-test or ANOVA with Dunn's post hoc test, if they were appropriate. $P$ values $<0.05$ were considered statistically significant.

\section{Results}

\section{Expression profile of genes related to POMC and transcription factors}

We first quantified steady-state mRNA levels POMC and transcription factors (NeuroD1 and Tpit) in ACTHsecreting tumors (CD and SCA) and NFT (Fig. 1). POMC mRNA levels in CD and SCA were about 136-fold $(P<0.01)$ and 5 -fold $(P<0.05)$ greater than those in NFT respectively. NeuroD1 mRNA levels in CD were less than those in SCA and NFT by about 45- to 65-fold $(P<0.05)$ respectively, whereas Tpit mRNA levels in CD and SCA were greater than those in NFT by about 26 -fold $(P<0.01)$ and 13 -fold $(P<0.05)$ respectively.

\section{Expression profile of genes related to secretion and processing of POMC and glucocorticoid- metabolizing enzymes}

Next we studied expression of genes related to regulation of ACTH secretion (CRHR and $\mathrm{V} 1 \mathrm{bR}$ ) in ACTH-secreting tumors (CD and SCA) and NFT (Fig. 2). CRHR mRNA levels in CD were greater than those in SCA and NFT by about 376- and 13-fold respectively $(P<0.01)$, while V1bR mRNA levels in CD and SCA were about 15- and 5-fold greater than those in NFT respectively $(P<0.01)$.

We then determined expression of genes related to POMC processing enzymes (PC1/3 and PC2) in ACTHsecreting tumors (CD and SCA) and NFT (Fig. 3a and $b$ ). $\mathrm{PC} 1 / 3$ mRNA levels were about threefold greater in CD $(P<0.01)$, but about fivefold lower in SCA $(P<0.05)$ than those in NFT respectively. By contrast, PC2 mRNA levels in CD and SCA were far less than those in NFT by 33- and 100-fold respectively $(P<0.05)$.

mRNA levels of $11 \beta$-HSD2 in CD, but not in SCA, were about fivefold greater than those in NFT $(P<0.05)$, whereas 11 $\beta$-HSD1 mRNA levels did not differ among the three tumor groups (Fig. $3 \mathrm{c}$ and $\mathrm{d}$ ). 
Table 1 PCR primers used for real-time RT-PCR.

\begin{tabular}{|c|c|c|}
\hline Primers & Sequences & PCR product size (bp) \\
\hline POMC & $\begin{array}{l}\text { Forward: CTACGGCGGTTTCATGACCT } \\
\text { Reverse: CCCTCACTCGCCCTTCTTG }\end{array}$ & 98 \\
\hline NeuroD1 & $\begin{array}{l}\text { Forward: GCCCCAGGGTTATGAGACTA } \\
\text { Reverse: GCTCCTCGTCCTGAGAACTG }\end{array}$ & 160 \\
\hline Tpit & $\begin{array}{l}\text { Forward: CTTTTGCCAAAGCCTTCTTG } \\
\text { Reverse: AGCGGCATACTGGTAATTGG }\end{array}$ & 167 \\
\hline CRHR & $\begin{array}{l}\text { Forward: CTCCTGGGCATCACCTACAT } \\
\text { Reverse: GACACAAAGAAGCCCTGGAA }\end{array}$ & 116 \\
\hline V1bR & $\begin{array}{l}\text { Forward: CAAGATCCGAACAGTGAAGATG } \\
\text { Reverse: CATAGAGATGGTGAAAGCCACA }\end{array}$ & 148 \\
\hline $\mathrm{PC} 1 / 3$ & $\begin{array}{l}\text { Forward: CGCTGACCTGCACAATGACT } \\
\text { Reverse: CAGACAACCAGGTGCTGCAT }\end{array}$ & 140 \\
\hline PC2 & $\begin{array}{l}\text { Forward: CTTGCAAAGGCCAAGAGAAG } \\
\text { Reverse: TTTCGGTCAAATCCTTCCTG }\end{array}$ & 101 \\
\hline $11 \beta-H S D 1$ & $\begin{array}{l}\text { Forward: CAATGGAAGCATTGTTGTCG } \\
\text { Reverse: GAAGAACCCATCCAAAGCAA }\end{array}$ & 100 \\
\hline $11 \beta-H S D 2$ & $\begin{array}{l}\text { Forward: GACCTGACCAAACCAGGAGA } \\
\text { Reverse: CCGCATCAGCAACTACTTCA }\end{array}$ & 121 \\
\hline $\mathrm{GR} \alpha$ & $\begin{array}{l}\text { Forward: GAACTGGCAGCGGTTTTATC } \\
\text { Reverse: CAGCTAACATCTCGGGGAAT }\end{array}$ & 151 \\
\hline ANXA1 & $\begin{array}{l}\text { Forward: GCTAAGGGTGACCGATCTGA } \\
\text { Reverse: ACGTCTGTCCCCTTTCTCCT }\end{array}$ & 104 \\
\hline HDAC2 & $\begin{array}{l}\text { Forward: CAGTTGCTGGAGCTGTGAAG } \\
\text { Reverse: AATTCAAGGATGGCAAGCAC }\end{array}$ & 139 \\
\hline Brg1 & $\begin{array}{l}\text { Forward: AGGCAAAATCCAGAAGCTGA } \\
\text { Reverse: CGCTTGTCCTTCTTCTGGTC }\end{array}$ & 165 \\
\hline Rab3A & $\begin{array}{l}\text { Forward: TGGGTTCGAGTTCTTTGAGG } \\
\text { Reverse: GTCCAACGACTCGGACATCT }\end{array}$ & 106 \\
\hline Syntaxin6 & $\begin{array}{l}\text { Forward: GACCCCTTCTTTGTGGTGAA } \\
\text { Reverse: TGGTCCAGTCGATTTCTTCC }\end{array}$ & 127 \\
\hline MARCH2 & $\begin{array}{l}\text { Forward: CTCAGCCTCCCAAGTAGCTG } \\
\text { Reverse: CTTGAGGCCAGGAGTTTGAG }\end{array}$ & 124 \\
\hline GAPDH & $\begin{array}{l}\text { Forward: GCTGAGAACGGGAAGCTTGT } \\
\text { Reverse: TCTCCATGGTGGTGAAGACG }\end{array}$ & 136 \\
\hline
\end{tabular}

POMC, proopiomelanocortin; NeuroD1, neurogenic differentiation 1; Tpit, T-box 19; CRHR, corticotropin releasing hormone receptor; V1bR, vasopressin

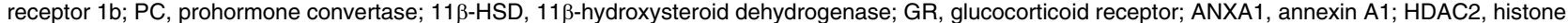
deacetylase 2; Brg1, BRM/SWI2-related gene 1; Rab, Ras-associated protein; MARCH, membrane associated ring finger protein; GAPDH, glyceraldehyde-3phosphate dehydrogenase. Expression profile of genes related to negative
feedback of POMC by glucocorticoid

Since abnormal negative feedback of POMC by glucocorticoid is the hallmark of $\mathrm{CD}$, we investigated the expression profile of several genes related to negative feedback regulation by glucocorticoids (GR $\alpha$, ANXA1, HDAC2, and Brg1) in ACTH-secreting tumors (CD and SCA) and NFT (Fig. 4). GR $\alpha$ mRNA levels did not differ among the three tumor groups, while ANXA1 mRNA levels were comparable between $\mathrm{CD}$ and SCA, but highly variable in NFT. HDAC2 mRNA levels in CD and SCA were (a)

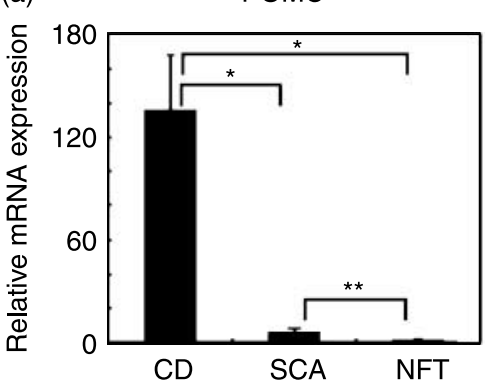

(b)

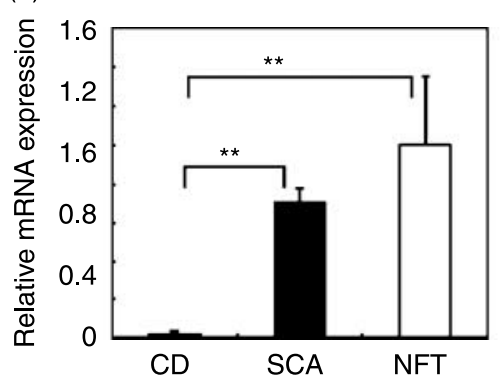

(c)

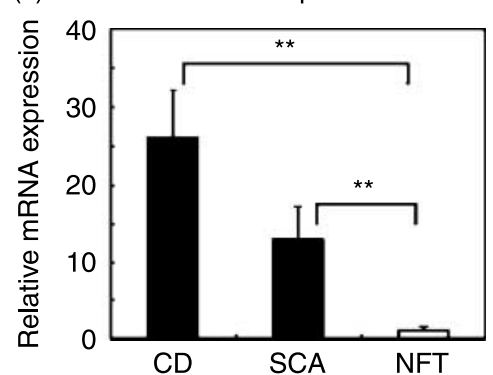

Figure 1 Expression profile of genes related to POMC and transcription factors (NeuroD1 and Tpit) in ACTH-secreting pituitary tumors (CD and SCA) and NFT. Steady-state mRNA levels of (a) POMC, (b) NeuroD1, and (c) Tpit as determined by real-time quantitative RT-PCR are shown. Data are expressed as fold increase over those of NFT (open column); each column is the mean; bar shows S.E.M. ${ }^{*} P<0.01$, ${ }^{\star *} P<0.05$. 

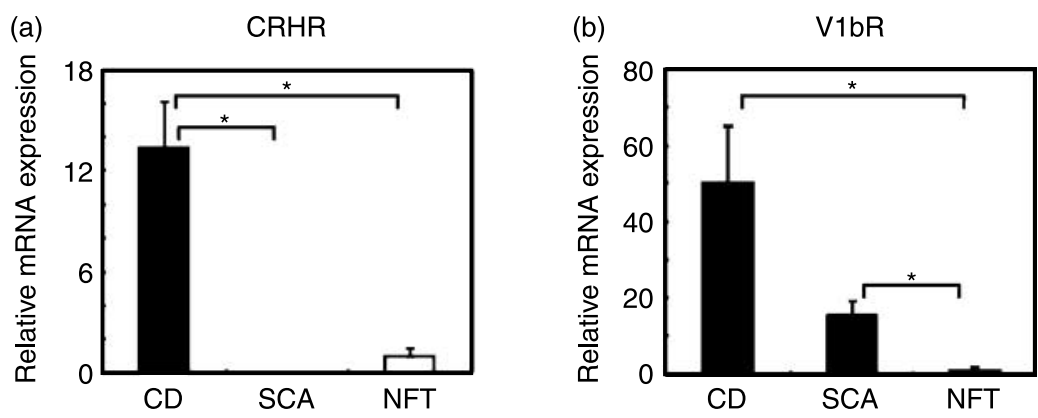

Figure 2 Expression profile of genes related to ACTH secretion (CRHR and V1bR) in ACTHsecreting pituitary tumors (CD and SCA) and NFT. Steady-state mRNA levels of (a) CRHR and (b) V1bR are shown. Data are calculated and plotted as in Fig. 1. ${ }^{*} P<0.01,{ }^{\star *} P<0.05$.

significantly $(P<0.05)$ less than those in NFT by about tenfold, while Brg1 mRNA levels were comparable between CD and SCA, but highly variable in NFT.

\section{Expression profile of genes related to intracellular hormone transport}

We finally examined expression profiles of genes related to intracellular hormone transport (Rab3A, syntaxin6, and MARCH2) in ACTH-secreting tumors (CD and SCA) and NFT. Either Rab3A, syntaxin6, or MARCH2 mRNA levels did not differ among the three tumor groups (data not shown).

\section{Discussion}

The present study using real-time quantitative RT-PCR demonstrates for the first time the differential expression profile of a variety of genes related to POMC transcription, synthesis, processing, and secretion in ACTHsecreting pituitary tumors compared with those in NFT. The LightCycler-based real-time RT-PCR protocol used in this study is considered to be more accurate than conventional techniques because the quantified copy numbers of any given transcripts are normalized with endogenous internal control (GAPDH). The present study clearly showed that ACTH-secreting pituitary tumors causing overt CD expressed far greater (136fold) POMC mRNA than NFT did and that POMC gene expression in SCA was fivefold greater than that in NFT.

NeuroD1, a basic helix-loop-helix transcription factor, in synergy with other transcription factor Ptx1, is involved in corticotroph-specific transcription of POMC gene and corticotroph cell differentiation (5). It has been reported that NeuroD1 mRNA was expressed in all 3 ACTH-secreting tumors as well as 6 out of 8 NFT by conventional RT-PCR, and NeuroD1 protein was detected (a)

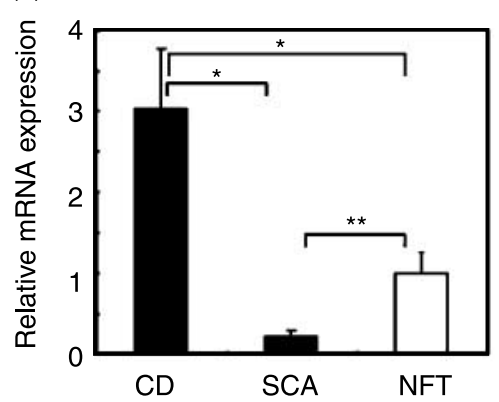

(c)

$11 \beta-H S D-2$

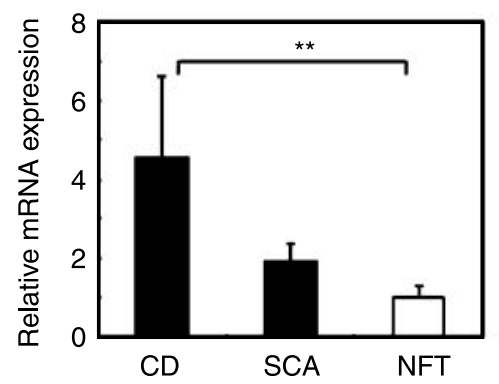

(b)

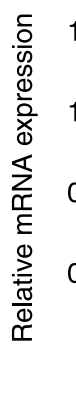

(d)

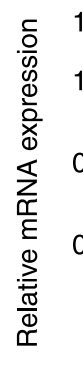

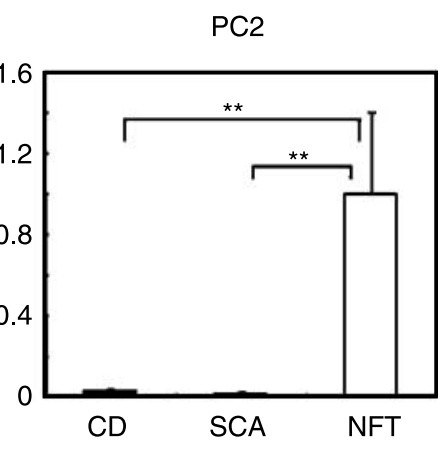

$11 \beta-H S D-1$

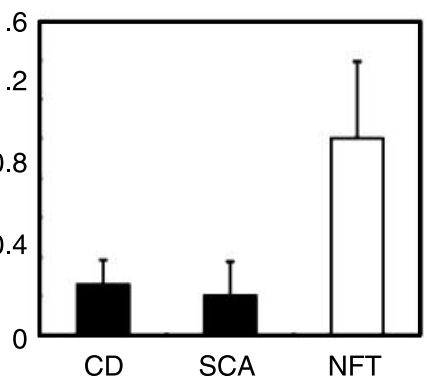

Figure 3 Expression profile of genes related to POMC processing (PC1/3 and $\mathrm{PC} 2$ ) and glucocorticoid-metabolizing enzymes (11 $\beta$-HSD1, -2) in ACTH-secreting pituitary tumors (CD and SCA) and NFT. Steady-state mRNA levels of (a) PC1/3, (b) PC2, (c) 11 $\beta$ HSD2, and (d) 11 $\beta$-HSD1 are shown. Data are calculated and plotted as in Fig. 1. ${ }^{\star} P<0.01$, ${ }^{\star *} P<0.05$ 
(a)

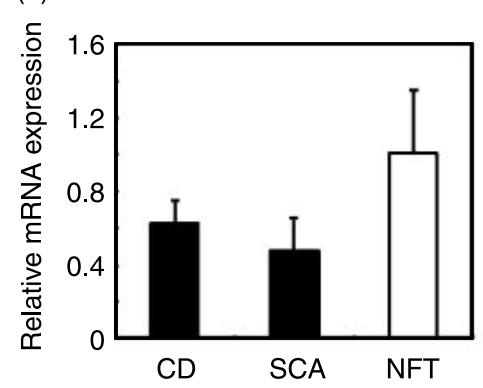

(c)

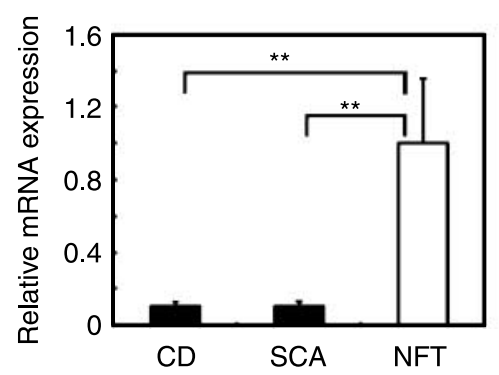

(b)

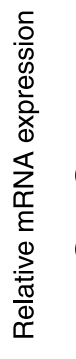

(d)

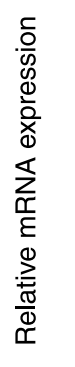

ANXA1

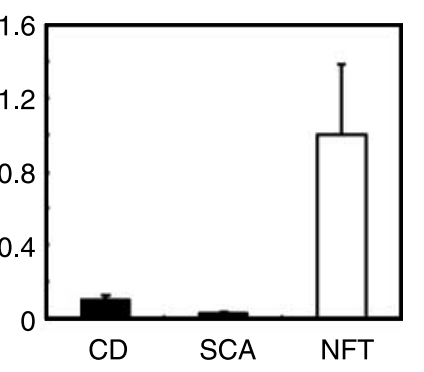

Brg1

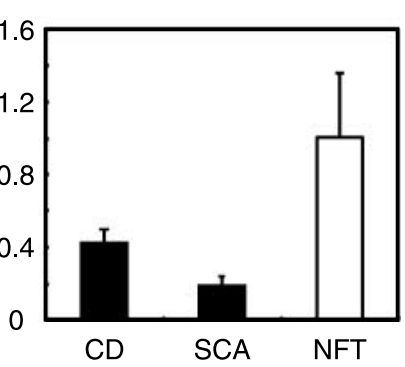

Figure 4 Expression profile of several genes related to negative feedback of POMC by glucocorticoid in ACTH-secreting pituitary tumors (CD and SCA) and NFT. Steady-state mRNA levels of (a) GR $\alpha$, (b) ANXA1,

(c) HDAC2, and (d) Brg1 are shown. Data are calculated and plotted as in Fig. 1. ${ }^{*} P<0.01$, ${ }^{* *} P<0.05$. in all 10 ACTH-secreting pituitary tumors as well as in 14 out of 20 NFT by immunohistochemical study (6), suggesting the important role of NeuroD1 in the functional expression and the differentiation of ACTHsecreting pituitary tumors. In contrast to those of a previous study (6), using small numbers of tumor samples and semiquantitative analyses, our data obtained from more cases with CD and SCA using more accurate and quantitative analysis by real-time RT-PCR clearly showed that ACTH-secreting pituitary tumors causing overt CD expressed far less NeuroD1 mRNA than did NFT and SCA. Thus, our data indicate that NeuroD1 is not sufficient per se to induce the transcription of POMC gene and the development of ACTH-secreting pituitary tumors.

Tpit, a member of transcription factors of the T-box family (7), plays a key role in the differentiation of corticotroph lineage (8). It has been shown that Tpit mRNA was detected and coexpressed with POMC mRNA in three ACTH-secreting pituitary tumors causing CD and one SCA by in situ hybridization study, while Tpit immunoreactivities were detected in 22 out of 26 (85\%) ACTH-secreting pituitary tumors, whereas Tpit mRNA was not detected in other type of pituitary tumors (9). Our study is consistent with those of a previous study (9), but further extends the idea that Tpit gene is expressed most abundantly in ACTH-secreting pituitary tumors causing overt CD and more in SCA than in NFT. Thus, our data lend credence to the notion that Tpit is essential for POMC transcription and corticotroph differentiation in ACTH-secreting pituitary tumors.

CRHR and V1bR, two specific receptors for potent ACTH secretagogues, CRH, and AVP respectively, have been reported to be overexpressed in ACTH-secreting pituitary tumors causing CD (10). Our data are consistent with those of previous studies, lending credence to the contention that patients with $\mathrm{CD}$ show hyperresponsiveness of ACTH release to $\mathrm{CRH}$ and vasopressin in vivo as well as in vitro (11-13). The present study, however, showed differential gene expression of CRHR and V1bR in SCA; increased V1bR and decreased CRHR mRNA levels. The increased V1bR gene expression in SCA raises the possibility that SCA patients may show responsiveness of ACTH release to vasopressin. Alternatively, the increased V1bR gene expression in SCA may be related to its tumor growth because vasopressin can also activate cAMP formation and phosphorylation of MAP kinases to induce mitogenic effects in cell lines overexpressing human V1bR (14). The decreased CRHR gene expression in SCA, on the other hand, may explain normal and/or subnormal ACTH secretion in most SCA patients (2). Taken together, it appears that there exists differential gene expression profiles of not only POMC and its processing enzymes (PC1/3 and PC3), but also of two major ACTH secretagogue receptors (CRHR and V1bR) between ACTH-secreting pituitary tumors causing CD and SCA.

Both $\mathrm{PC} 1 / 3$ and PC2 are involved in the posttranslational proteolytic processing of polypeptide hormones in endocrine tissues, including pancreatic islets and pituitary glands. $\mathrm{PC} 1 / 3$ is a cleaving enzyme responsible for the post-translational processing of POMC into mature ACTH (1-39) in corticotrophs of the anterior pituitary, while PC2 is responsible for the proteolytic processing of mature ACTH (1-39) into $\alpha$-melanocyte stimulating hormone $(\alpha-\mathrm{MSH})$ and its C-terminal fragment, termed corticotropin-like 
intermediate lobe pepetide, in the intermediate lobe of the pituitary gland $(15,16)$. It has been shown that both $\mathrm{PC} 1 / 3$ and PC2 mRNA are expressed in ACTHsecreting pituitary tumors and NFT by conventional RT-PCR (17), and that immunoreactivities of both PC1/ 3 and PC2 are detected in the normal pituitary gland by immunohistochemical study, while immunoreactivity for $\mathrm{PC} 1 / 3$ is more abundant in ACTH-secreting pituitary tumors causing $\mathrm{CD}(15,16,18)$. However, $\mathrm{PC} 1 / 3$ expression in SCA by immunochemical study has shown conflicting results; negative immunoreactive $\mathrm{PC} 1 / 3$ in one case (19) versus positive immunoreactive $\mathrm{PC} 1 / 3$ in four cases $(20,21)$.

Our data clearly showed that ACTH-secreting pituitary tumors causing overt $\mathrm{CD}$ expressed far greater (136-fold) POMC mRNA associated with threefold more PC1/3 and 33-fold less PC2 mRNA expression than did NFT. The present results of the concomitant enhanced expressions of $\mathrm{POMC}$ and $\mathrm{PC} 1 / 3$ genes accompanied by decreased PC2 gene expression in ACTH-secreting pituitary tumors are consistent with accelerated processing of POMC into mature ACTH(1-39), thus causing overt $\mathrm{CD}$. By contrast, our study showed that POMC gene expression in SCA was higher than that in NFT, but far less than that in $\mathrm{CD}$, and that $\mathrm{PC} 1 / 3$ and PC2 gene expressions were concomitantly decreased in SCA. Such differential gene expression of increased POMC with decreased PC1/3 and PC2 in SCA may lead to impaired processing of less bioactive POMC and/or proACTH into mature ACTH(1-39) (22-24), thereby partly accounting for silent or subclinical manifestations of Cushing's syndrome in SCA. However, the molecular mechanism for the concomitant decreased expression of $\mathrm{PC} 1 / 3$ and $\mathrm{PC} 2$ in SCA remains undetermined.

Two isoenzymes of 11ß-HSD type 1 that converts cortisone (E) to cortisol (F), and type 2 that converts $\mathrm{F}$ to $\mathrm{E}$, play important roles in regulating glucocorticoid hormone action in several tissues, including the anterior pituitary where they can modulate the negative feedback mechanism by glucocorticoids. It has been reported that ACTH-secreting pituitary tumors show enhanced $11 \beta$-HSD2 gene expression, but suppressed 11 $\beta$-HSD1 gene expression $(25,26)$. These data are consistent with the enhanced 11 $\beta$-HSD2 gene expression in ACTHsecreting pituitary tumors causing $\mathrm{CD}$, but not in SCA or NFT as demonstrated in this study. Therefore, the increased 11ß-HSD2 mRNA expression in ACTH-secreting pituitary tumors might in part explain the partial resistance by glucocorticoids to the negative feedback mechanism in CD.

Although alternation of GR $\alpha$ gene expression has been shown in some ACTH-secreting pituitary tumors, but is normal in most cases (27), polymorphisms in the GR gene and the frequent loss of heterozygosity $(\mathrm{LOH})$ at the GR gene locus may account for the glucocorticoid resistance in the negative feedback mechanism (27-29). The present study did not show any change in GR $\alpha$ gene expression in ACTH-secreting pituitary tumors (CD, SCA), suggesting that the involvement of quantitative defects of GR $\alpha$ gene expression in glucocorticoid resistance in ACTH-secreting pituitary tumors seems remote, although the polymorphisms and/or LOH of the GR $\alpha$ gene as well as defect in peripheral GR and/ or postreceptor targets remains to be determined.

It has been reported that ANXA1 acts as a paracrine or juxtacrine mediator of the early inhibitory effects of glucocorticoids on ACTH secretion in the rat anterior pituitary $(30,31)$. However, our data showed variable gene expressions of ANXA1 in NFT when compared with its stable expression in ACTH-secreting pituitary tumors. Thus, the possible involvement of ANXA1 in dysregulation of ACTH secretion in ACTH-secreting pituitary tumors seems unlikely.

Acetylation of histones, which allows unwinding of the local DNA structure and enables RNA polymerase II to enhance gene transcription, is regulated by a balance between histone acetyltransferases and $\operatorname{HDACs}(32,33)$, while GR recruits HDAC2 to the activated gene to switch off transcription (34). Brg1, an ATPase subunit of the SWI/SNF chromatin remodeling complex (35), by interacting with GR allows chromatin remodeling (36). It has been reported that HDAC2 and Brg1 are important for glucocorticoid-induced transrepression of the POMC gene in the negative feedback regulation mechanism, and that immunoreactivities of either HDAC2 or Brg1 were deficient in 17 out of $36(48 \%)$ ACTH-secreting pituitary tumors (37). Our data clearly showed that HDAC2 mRNA expression is consistently and markedly decreased in all ACTH-secreting pituitary tumors causing CD and SCA, although Brg1 mRNA expression did not differ among the three tumor groups. Therefore, the decreased HDAC2 expression rather than Brg1 expression may partly play a more important role in the partial resistance by glucocorticoids to the negative feedback mechanism in CD.

Recently, it has been reported that a variety of synaptic proteins are involved in neuronal membrane traffic. For example, Rab3A and syntaxin which are involved in exocytosis in the secretory pathway in the rat anterior pituitary (38), and immunoreactivities of Rab3A are positive in human pituitary adenoma (39), and MARCH2, a recently identified member of the mammalian E3 ubiquitin ligase family, localize to endosomal vesicles and the plasma membrane, and associate with syntaxin6 (40). Our data showed no apparent differences in mRNA expression of either Rab3A, syntaxin 6 or MARCH2 in ACTH-secreting pituitary tumors and NFT (data not shown), suggesting that the alteration of genes related to intracellular hormone transport is not involved in the secretory pathway in ACTH-secreting pituitary tumors.

In conclusion, the present study on the expression profile of a variety of genes related to POMC transcription, synthesis, processing, and secretion in ACTHsecreting pituitary tumors revealed markedly enhanced expression of POMC and Tpit with concomitantly 
increased expression of PC1/3, CRHR, and V1bR in ACTH-secreting pituitary tumors could lead to clinically active or overt CD, while increased 11ß-HSD2 and decreased HDAC2 expression may partly explain the impaired negative feedback regulation by glucocorticoids in CD. By contrast, only a mildly increased expression of POMC and Tpit associated with reduced PC1/3 and CRHR expression in SCA may lead to production of less ACTH and/or secretion of less biologically active unprocessed POMC, accounting in part for clinically inactive or subclinical CD.

\section{Acknowledgements}

This study was supported in part by Grants-in-Aid from the Ministry of Education, Culture, Sports, Science and from the Ministry of Health, Labor and Welfare, Japan.

\section{References}

1 Horvath E, Kovacs K, Killinger DW, Smyth HS, Platts ME \& Singer W. Silent corticotropic adenomas of the human pituitary gland: a histologic, immunocytologic, and ultrastructural study. American Journal of Pathology 198098 617-638.

2 Reincke M, Allolio B, Saeger W, Kaulen D \& Winkelmann W. A pituitary adenoma secreting high molecular weight adrenocorticotropin without evidence of Cushing's disease. Journal of Clinical Endocrinology and Metabolism 198765 1296-1300.

3 Morris D \& Grossman A. The medical management of Cushing's syndrome. Annals of the New York Academy of Sciences 2002970 119-133.

4 Evans CO, Young AN, Brown MR, Brat DJ, Parks JS, Neish AS \& Oyesiku NM. Novel patterns of gene expression in pituitary adenomas identified by complementary deoxyribonucleic acid microarrays and quantitative reverse transcription-polymerase chain reaction. Journal of Clinical Endocrinology and Metabolism 200186 3097-3107.

5 Poulin G, Turgeon B \& Drouin J. NeuroD1/beta2 contributes to cell-specific transcription of the proopiomelanocortin gene. Molecular and Cellular Biology 199717 6673-6682.

6 Oyama K, Sanno N, Teramoto A \& Osamura RY. Expression of neuro D1 in human normal pituitaries and pituitary adenomas. Modern Pathology 200114 892-899.

7 Herrmann BG, Labeit S, Poustka A, King TR \& Lehrach H. Cloning of the $\mathrm{T}$ gene required in mesoderm formation in the mouse. Nature $1990343617-622$.

8 Lamolet B, Pulichino AM, Lamonerie T, Gauthier Y, Brue T, Enjalbert A \& Drouin J. A pituitary cell-restricted T box factor, Tpit, activates POMC transcription in cooperation with Pitx homeoproteins. Cell $2001 \mathbf{1 0 4} 849-859$.

9 Vallette-Kasic S, Figarella-Branger D, Grino M, Pulichino AM, Dufour H, Grisoli F, Enjalbert A, Drouin J \& Brue T. Differential regulation of proopiomelanocortin and pituitary-restricted transcription factor (TPIT), a new marker of normal and adenomatous human corticotrophs. Journal of Clinical Endocrinology and Metabolism $2003 \mathbf{8 8} 3050-3056$.

10 de Keyzer Y, Rene P, Beldjord C, Lenne F \& Bertagna X. Overexpression of vasopressin (V3) and corticotrophin-releasing hormone receptor genes in corticotroph tumours. Clinical Endocrinology $1998 \mathbf{4 9} 475-482$.

11 Raux MC, Binoux M, Luton JP, Gourmelen M \& Girard F. Studies of ACTH secretion control in 116 cases of Cushing's syndrome. Journal of Clinical Endocrinology and Metabolism 197540 186-197.
12 Dickstein G, DeBold CR, Gaitan D, DeCherney GS, Jackson RV, Sheldon WR, Jr, Nicholson WE \& Orth DN. Plasma corticotropin and cortisol responses to ovine corticotropin-releasing hormone (CRH), arginine vasopressin (AVP), $\mathrm{CRH}$ plus AVP, and $\mathrm{CRH}$ plus metyrapone in patients with Cushing's disease. Journal of Clinical Endocrinology and Metabolism $1996 \mathbf{8 1} 2934-2941$.

13 Fukata J, Shimizu N, Imura H, Hibi I, Tanaka K, Tanaka T, Nakagawa S, Takebe K, Kimura K Yoshinaga K et al. Human corticotropin-releasing hormone test in patients with hypothalamo-pituitary-adrenocortical disorders. Endocrine Journal 1993 40 597-606.

14 Thibonnier M, Preston JA, Dulin N, Wilkins PL, Berti-Mattera LN \& Mattera R. The human V3 pituitary vasopressin receptor: ligand binding profile and density-dependent signaling pathways. Endocrinology $1997 \mathbf{1 3 8} 4109-4122$.

15 Takumi I, Steiner DF, Sanno N, Teramoto A \& Osamura RY. Localization of prohormone convertases $1 / 3$ and 2 in the human pituitary gland and pituitary adenomas: analysis by immunohistochemistry, immunoelectron microscopy, and laser scanning microscopy. Modern Pathology $199811232-238$.

16 Scopsi L, Gullo M, Rilke F, Martin S \& Steiner DF. Proprotein convertases (PC1/PC3 and $\mathrm{PC} 2)$ in normal and neoplastic human tissues: their use as markers of neuroendocrine differentiation. Journal of Clinical Endocrinology and Metabolism $199580294-301$.

17 Jin L, Zhang S, Bayliss J, Scheithauer B, Qian X, Kobayashi I, Stridsberg M \& Lloyd RV. Chromogranin a processing in human pituitary adenomas and carcinomas: analysis with region-specific antibodies. Endocrine Pathology 200314 37-48.

18 Lloyd RV, Jin L, Qian X, Scheithauer BW, Young WF Jr \& Davis DH. Analysis of the chromogranin A post-translational cleavage product pancreastatin and the prohormone convertases PC2 and PC3 in normal and neoplastic human pituitaries. American Journal of Pathology $1995 \mathbf{1 4 6} 1188-1198$.

19 Ohta S, Nishizawa S, Oki Y, Yokoyama T \& Namba H. Significance of absent prohormone convertase $1 / 3$ in inducing clinically silent corticotroph pituitary adenoma of subtype I - immunohistochemical study. Pituitary $20025221-223$.

20 Matsuno A, Okazaki R, Oki Y \& Nagashima T. Secretion of highmolecular-weight adrenocorticotropic hormone from a pituitary adenoma in a patient without Cushing stigmata. Case report. Journal of Neurosurgery $2004101874-877$.

21 Iino K, Oki Y, Matsushita F, Yamashita M, Hayashi C, Miura K, Nishizawa S \& Nakamura H. Immunohistochemical properties of silent corticotroph adenoma and Cushing's disease. Pituitary 2007 $1035-45$.

22 Hirata Y, Yamamoto H, Matsukura S \& Imura H. In vitro release and biosynthesis of tumor ACTH in ectopic ACTH producing tumors. Journal of Clinical Endocrinology and Metabolism $1975 \mathbf{4 1}$ 106-114.

23 Gewirtz G, Schneider B, Krieger DT \& Yalow RS. Big ACTH: conversion to biologically active ACTH by trypsin. Journal of Clinical Endocrinology and Metabolism 197438 227-230.

24 Ratter SJ, Gillies G, Hope J, Hale AC, Grossman A, Gaillard R, Cook D, Edwards CR \& Rees LH. Pro-opiocortin related peptides in human pituitary and ectopic ACTH secreting tumours. Clinical Endocrinology 198318 211-218.

25 Korbonits M, Bujalska I, Shimojo M, Nobes J, Jordan S, Grossman AB \& Stewart PM. Expression of 11 beta-hydroxysteroid dehydrogenase isoenzymes in the human pituitary: induction of the type 2 enzyme in corticotropinomas and other pituitary tumors. Journal of Clinical Endocrinology and Metabolism $2001 \mathbf{8 6}$ 2728-2733.

26 Parks LL, Turney MK, Gaitan D \& Kovacs WJ. Expression of 11beta-hydroxysteroid dehydrogenase type 2 in an ACTHproducing small cell lung cancer. Journal of Steroid Biochemistry and Molecular Biology 199867 341-346.

27 Huizenga NA, de Lange P, Koper JW, Clayton RN, Farrell WE, van der Lely AJ, Brinkmann AO, de Jong FH \& Lamberts SW. Human adrenocorticotropin-secreting pituitary adenomas show 
frequent loss of heterozygosity at the glucocorticoid receptor gene locus. Journal of Clinical Endocrinology and Metabolism 199883 917-921.

28 Mu YM, Takayanagi R, Imasaki K, Ohe K, Ikuyama S, Yanase T \& Nawata H. Low level of glucocorticoid receptor messenger ribonucleic acid in pituitary adenomas manifesting Cushing's disease with resistance to a high dose-dexamethasone suppression test. Clinical Endocrinology 199849 301-306.

29 Antonini SR, Latronico AC, Elias LL, Cukiert A, Machado HR, Liberman B, Mendonca BB, Moreira AC \& Castro M. Glucocorticoid receptor gene polymorphisms in ACTH-secreting pituitary tumours. Clinical Endocrinology 200257 657-662.

30 Tierney T, Christian HC, Morris JF, Solito E \& Buckingham JC. Evidence from studies on co-cultures of TtT/GF and AtT20 cells that Annexin 1 acts as a paracrine or juxtacrine mediator of the early inhibitory effects of glucocorticoids on ACTH release. Journal of Neuroendocrinology 200315 1134-1143.

31 Solito E, Mulla A, Morris JF, Christian HC, Flower RJ \& Buckingham JC. Dexamethasone induces rapid serine-phosphorylation and membrane translocation of annexin 1 in a human folliculostellate cell line via a novel nongenomic mechanism involving the glucocorticoid receptor, protein kinase $\mathrm{C}$, phosphatidylinositol 3-kinase, and mitogen-activated protein kinase. Endocrinology $2003 \mathbf{1 4 4} 1164-1174$.

32 Turner BM. Histone acetylation and control of gene expression. Journal of Cell Science 199199 13-20.

33 Kouzarides T. Histone acetylases and deacetylases in cell proliferation. Current Opinion in Genetics and Development 19999 40-48.

34 Ito K, Barnes PJ \& Adcock IM. Glucocorticoid receptor recruitment of histone deacetylase 2 inhibits interleukin-1beta-induced histone $\mathrm{H} 4$ acetylation on lysines 8 and 12. Molecular and Cellular Biology 200020 6891-6903.
35 Vradii D, Wagner S, Doan DN, Nickerson JA, Montecino M, Lian JB, Stein JL, van Wijnen AJ, Imbalzano AN \& Stein GS. Brg1, the ATPase subunit of the SWI/SNF chromatin remodeling complex, is required for myeloid differentiation to granulocytes. Journal of Cellular Physiology 2006206 112-118.

36 Fryer CJ \& Archer TK. Chromatin remodelling by the glucocorticoid receptor requires the BRG1 complex. Nature 1998393 88-91.

37 Bilodeau S, Vallette-Kasic S, Gauthier Y, Figarella-Branger D, Brue T, Berthelet F, Lacroix A, Batista D, Stratakis C, Hanson J, Meij B \& Drouin J. Role of Brg1 and HDAC2 in GR trans-repression of the pituitary POMC gene and misexpression in Cushing disease. Genes and Development 200620 2871-2886.

38 Aguado F, Majo G, Ruiz-Montasell B, Canals JM, Casanova A, Marsal J \& Blasi J. Expression of synaptosomal-associated protein SNAP-25 in endocrine anterior pituitary cells. European Journal of Cell Biology 199669 351-359.

39 Majo G, Ferrer I, Marsal J, Blasi J \& Aguado F. Immunocytochemical analysis of the synaptic proteins SNAP-25 and Rab3A in human pituitary adenomas. Overexpression of SNAP-25 in the mammmosomatotroph lineages. Journal of Pathology 1997183 440-446.

40 Nakamura N, Fukuda H, Kato A \& Hirose S. MARCH-II is a syntaxin-6-binding protein involved in endosomal trafficking. Molecular Biology of the Cell 200516 1696-1710.

Received 8 September 2007

Accepted 25 September 2007 